\title{
The Forest Mound Site (41CE290) on Larrison Creek, Cherokee County, Texas
}

Timothy K. Perttula

Heritage Research Center, Stephen F. Austin State University

Follow this and additional works at: https://scholarworks.sfasu.edu/ita

Part of the American Material Culture Commons, Archaeological Anthropology Commons, Environmental Studies Commons, Other American Studies Commons, Other Arts and Humanities Commons, Other History of Art, Architecture, and Archaeology Commons, and the United States History Commons

Tell us how this article helped you.

This Article is brought to you for free and open access by the Center for Regional Heritage Research at SFA ScholarWorks. It has been accepted for inclusion in Index of Texas Archaeology: Open Access Gray Literature from the Lone Star State by an authorized editor of SFA ScholarWorks. For more information, please contact cdsscholarworks@sfasu.edu. 


\section{The Forest Mound Site (41CE290) on Larrison Creek, Cherokee County, Texas \\ Creative Commons License \\ (c) $($ ) (9)}

This work is licensed under a Creative Commons Attribution-NonCommercial 4.0 International License 


\title{
The Forest Mound Site (41CE290) on Larrison Creek, Cherokee County, Texas
}

\author{
Timothy K. Perttula
}

\section{INTRODUCTION}

The Forest Mound site (41CE290) is an ancestral Caddo site on a sandy knoll on an alluvial terrace of Larrison Creek, a southward-flowing tributary to the Neches River in the East Texas Pineywoods (Figure 1). Raymond Ring, an avocational archaeologist, found and investigated the site in 1962, and amassed a small collection of ceramic sherds and one arrow point that he subsequently donated to the Texas Archeological Research Laboratory at The University of Texas at Austin (TARL).

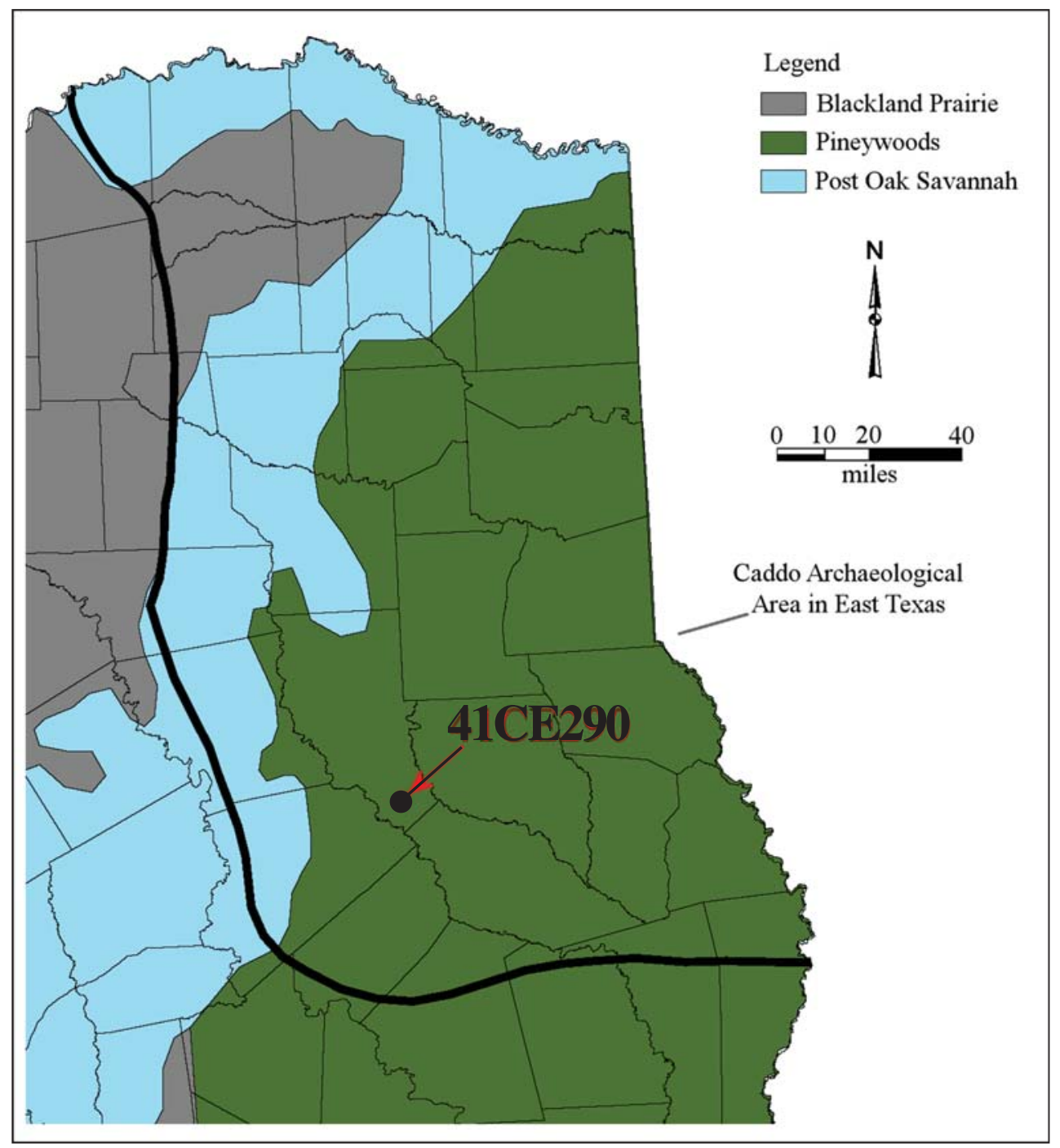

Figure 1. The location of the Forest Mound site (41CE290) in East Texas. 


\section{SITE INVESTIGATIONS}

A Shell Oil pipeline had cut through one end of a large (ca. $>60 \mathrm{~m}$ in diameter and $2.5 \mathrm{~m}$ in height) knoll, and in 1962 Raymond Ring noted and described a cultural feature visible in the profile. It appears that the pipeline had cut through a burned Caddo structure at ca. $107 \mathrm{~cm} \mathrm{bs}$; the source of the sandy sediments above the burned structure is not known, nor is it known if they are naturally or artificially deposited atop the burned structure.

The burned structure was marked by a ca. $2.5 \mathrm{~cm}$ thick lens of charcoal and pieces of fired clay. Ring also excavated a Caddo burial that was in a shallow pit (ca. $107-137 \mathrm{~cm}$ bs) associated with the burned structure.

\section{ARTIFACT ASSEMBLAGE}

Ring collected from the profile cut through the knoll a single petrified wood Alba arrow point and 197 Caddo ceramic sherds, tempered with grog and grog-bone; these artifacts have been donated to TARL. The ceramic sherds include 96 plain rim, body, and base sherds (among them seven plain sherds from bottles) and 101 decorated sherds (Table 1).

Table 1. Decorated sherds in the TARL collections from the Forest Mound site (41CE290).

\begin{tabular}{llrr}
\hline Ware & Decorative Method & $\mathrm{N}$ & Percent \\
\hline Utility & & & \\
& Brushed & 24 & 23.8 \\
& Brushed-Punctated & 1 & 1.0 \\
& Incised \\
& Incised-Punctated & 10 & 9.9 \\
& Punctated & 2 & 2.0 \\
& & 30 & 29.7 \\
Fine & Engraved & 34 & 33.6 \\
\hline Totals & & 101 & 100.0 \\
\hline
\end{tabular}

The sherds from utility ware vessels from the Forest Mound site are dominated by sherds with punctated and brushed decorative methods (see Table 1). These account for 53.5 percent of the decorated sherd assemblage. The incised and incised-punctated sherds are from slightly everted rim Maydelle Incised vessels (see Suhm and Jelks 1962:103). They have diagonal incised lines on the rim as well as diagonal opposed lines and triangular-shaped zones filled with tool punctations (Figure 2a-c).

The engraved sherds in the TARL collections from the Forest Mound site are from both bottles and carinated bowls with polished vessel surfaces. The bottle sherds have horizontal and curvilinear engraved lines (possibly from a Holly Fine Engraved bottle, see Suhm and Jelks 1962:77, 79), curvilinear and triangular excised areas with negative ovals and triangle elements, and a red-slipped bottle with hatched pendant triangles (Figure 3h).

Most of the engraved sherds from carinated bowls are from Holly Fine Engraved vessels (see Figure $3 \mathrm{a}-\mathrm{c}, \mathrm{e}, \mathrm{g})$; they commonly have red pigment rubbed in the engraved lines. These sherds have diagonal and 


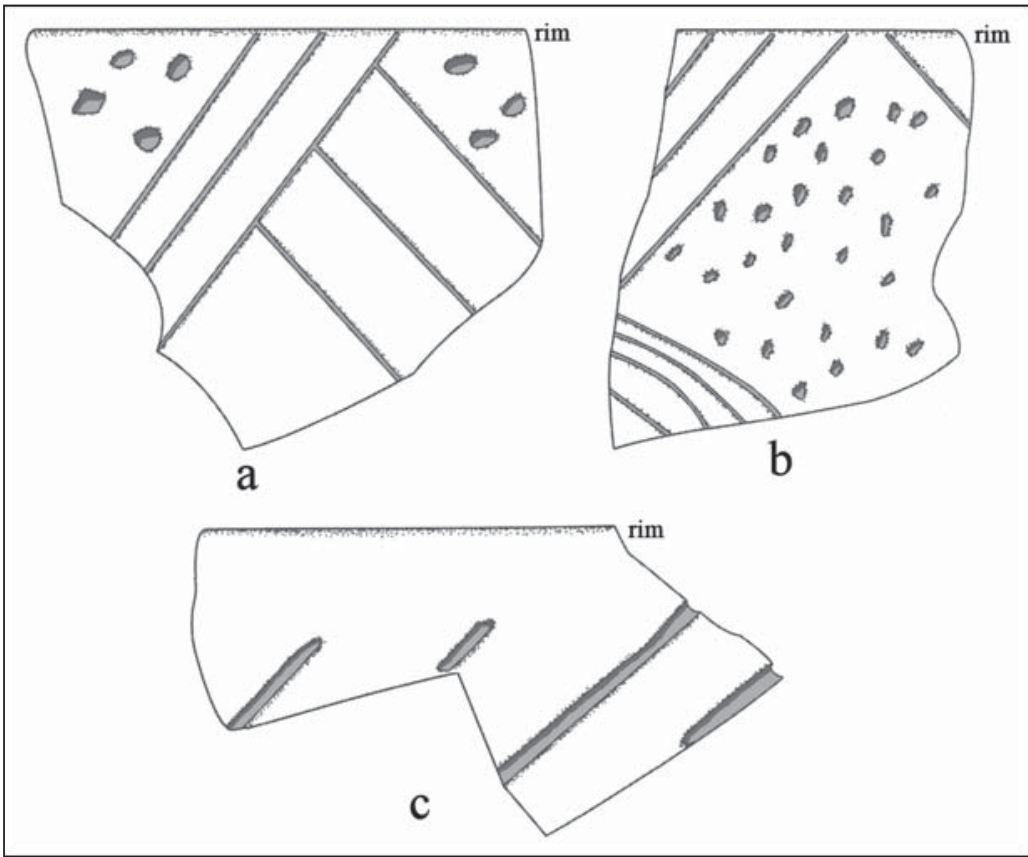

Figure 2. Maydelle Incised rim sherds from the Forest Mound site.

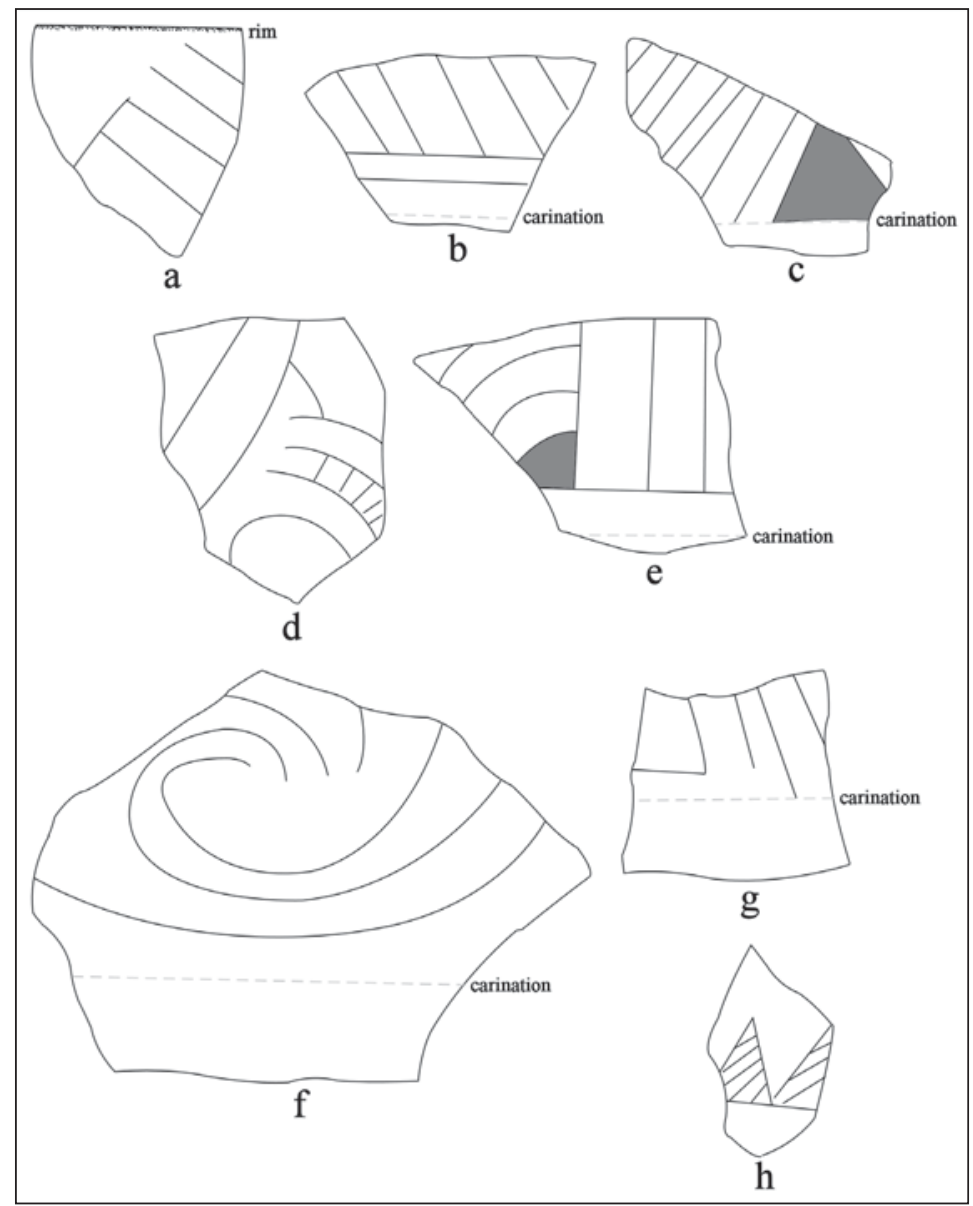

Figure 3. Selected decorative elements on engraved sherds from the Forest Mound site: a-g, carinated bowl sherds; h, bottle sherd. 
diagonal opposed lines, with triangular excised areas (see Figure 3c, e, and g) or vertical and curvilinear engraved lines with a curvilinear excised area above the vessel carination (see Figure $3 \mathrm{e}$ ).

One carinated bowl sherd from the Forest Mound has opposed curvilinear and semi-circular engraved elements along with hatched and cross-hatched zones (see Figure 3d). The last engraved sherd is the lower rim panel and upper body of a carinated bowl (see Figure 3f): it has sets of curvilinear engraved lines that end in a hooked arm element. Neither of these two engraved sherds are from a known Caddo ceramic type.

\section{SUMMARY AND CONCLUSIONS}

The Forest Mound site (41CE290) is on a tributary to the Neches River, in the East Texas Pineywoods. Investigations of the site in 1962 by Raymond Ring identified the remnants of a burned ancestral Caddo structure in a profile cut into a large natural knoll by a pipeline. Associated with this burned structure was a single Caddo burial in a shallow pit.

If the ceramic assemblage collected by Raymond Ring from the Forest Mound site represents a single component, which seems likely given the described archaeological context of the finds, then it appears that the site was occupied in the Middle Caddo period, from perhaps ca. A.D. 1200-1300, or even somewhat later. The site was likely occupied at the very end (ca. A.D. 1300) of the substantial ancestral Caddo component at the George C. Davis site (41CE19), given the common occurrence of Holly Fine Engraved sherds at both sites (see Newell and Krieger 1949; Story 1997, 1998, 2000). The frequency of brushed sherds in the Forest Mound assemblage (24.8 percent of the decorated sherds) clearly points then to a late 13th to early 14 th century A.D. Caddo occupation there, because sherds from brushed utility ware vessels in East Texas begin to be common in Caddo assemblages about that time (Perttula 2015).

\section{ACKNOWLEDGMENTS}

I thank Jonathan Jarvis at the Texas Archeological Research Laboratory at The University of Texas at Austin for facilitating access to the collections and records from the Forest Mound site. Lance Trask prepared the figures in this article.

\section{REFERENCES CITED}

Newell, H. P and A. D. Krieger

1949 The George C. Davis Site, Cherokee County, Texas. Memoir No. 5. Society for American Archaeology, Menasha, Wisconsin.

Perttula, T. K.

2015 East Texas Caddo Ceramic Sherd Database. Journal of Northeast Texas Archaeology 51:1-46.

Story, D. A.

1997 1968-1970 Archeological Investigations at the George C. Davis Site, Cherokee County, Texas. Bulletin of the Texas Archeological Society 68:1-113.

1998 The George C. Davis Site: Glimpses into Early Caddoan Symbolism and Ideology. In The Native History of the Caddo: Their Place in Southeastern Archeology and Ethnohistory, edited by T. K. Perttula and J. E. Bruseth, pp. 9-43. Studies in Archeology 30. Texas Archeological Research Laboratory The University of Texas at Austin. 
2000 Introduction. In The George C. Davis Site, Cherokee County, Texas, by H. P. Newell and A. D. Krieger, pp. 1-31.2nd Edition. Society for American Archaeology, Washington, D.C.

Suhm, D. A. and E. B. Jelks (editors)

1962 Handbook of Texas Archeology: Type Descriptions. Special Publication No. 1, Texas Archeological Society, and Bulletin No. 4, Texas Memorial Museum, Austin. Reprinted in 2009, Gustav's Library, Davenport, Iowa. 